\title{
Kinetics and avidity of anti-Toxocara antibodies (IgG) in rabbits experimentally infected with Toxocara canis
}

\author{
Cinética e avidez de anticorpos ( $\mathrm{IgG}$ ) anti-Toxocara em coelhos \\ experimentalmente infectados com Toxocara canis
}

Lundia Luara Cavalcante Bin ${ }^{1}$; Vamilton Alvares Santarém ${ }^{2 *}$; Cecília Braga Laposy ${ }^{3}$;

Guita Rubinsky-Elefantt ${ }^{4}$; William Henry Roldán ${ }^{4}$; Rogério Giuffrida ${ }^{1}$

\author{
${ }^{1}$ Programa de Pós-Graduação em Ciência Animal, Universidade do Oeste Paulista - UNOESTE, Presidente Prudente, SP, Brasil \\ ${ }^{2}$ Programa de Pós-Graduação em Ciência Animal, Laboratório de Parasitologia Veterinária, Hospital Veterinário, Universidade do \\ Oeste Paulista - UNOESTE, Presidente Prudente, SP, Brasil \\ ${ }^{3}$ Programa de Pós-Graduação em Ciência Animal, Laboratório de Patologia Clínica Veterinária, Hospital Veterinário, Universidade do \\ Oeste Paulista - UNOESTE, Presidente Prudente, SP, Brasil \\ ${ }^{4}$ Laboratório de Seroepidemiologia e Imunonobiologia, Instituto de Medicina Tropical de São Paulo, Universidade de São Paulo - \\ USP, São Paulo, SP, Brasil
}

Received March 2, 2015

Accepted June 19, 2015

\begin{abstract}
An evaluation was made of the kinetics and avidity of anti-Toxocara antibodies (IgG) in rabbits experimentally infected with embryonated Toxocara canis eggs. Seventeen four month old New Zealand White rabbits were distributed into two groups. In the experimental group, twelve rabbits were infected orally with 1,000 embryonated T. canis eggs. A second group $(n=5)$, uninfected, was used as a control. Serum samples were collected for analysis on days 7, 14, 21, 28 and 60 post-infection (DPI). An indirect ELISA test was performed to evaluate the reactivity index (RI) of IgG anti-T. canis antibodies and to calculate the avidity index (AI). The animals showed seroconversion from the $14^{\text {th }}$ DPI, with high AI (over 50\%) except for one animal, which presented an intermediate AI. At 60 DPI, all the animals were seropositive and maintained a high AI. The data indicated that specific IgG antibodies formed early (14 DPI) in rabbits infected with T. canis, with a high avidity index that persisted throughout the course of the infection.
\end{abstract}

Keywords: Toxocariasis, antibody avidity, immune response, ELISA.

\section{Resumo}

O objetivo deste estudo foi o de avaliar a cinética e a avidez de anticorpos anti-Toxocara canis, em coelhas infectadas experimentalmente com ovos embrionados de Toxocara canis. Foram utilizados 17 coelhos New Zealand de linhagem branca, com quatro meses de idade, distribuídos em dois grupos. No grupo experimental, doze coelhas foram infectadas, oralmente, com 1.000 ovos larvados de T. canis. Um segundo grupo ( $\mathrm{n}=5)$, náo infectado, foi utilizado como controle. Nos dias 7, 14, 21, 28 e 60 pós-infecção (DPI), foram coletadas amostras de soro para análise. O teste de ELISA indireto foi realizado para avaliar o índice de reatividade (IR) de anticorpos IgG anti-T. canis e para cálculo do índice de avidez (IA). A soroconversão nos animais ocorreu a partir do $14^{0} \mathrm{DPI}$, com verificação de alto IA (superior a 50\%), com exceção de um animal, que apresentou médio IA. Aos $60 \mathrm{DPI}$, todos os animais foram soropositivos e mantiveram alto IA. Os dados mostram que em coelhos infectados por T. canis, anticorpos IgG específicos formam-se precocemente (14 DPI), apresentando alto índice de avidez e que se mantém durante o curso da infecção.

Palavras-chave: Toxocaríase, avidez de anticorpos, resposta imune, ELISA.

*Corresponding author: Vamilton Alvares Santarém. Programa de Pós-Graduação em Ciência Animal, Universidade do Oeste Paulista UNOESTE, Rodovia Raposo Tavares, Km 572, Bairro Limoeiro, CEP 19067 -

175, Presidente Prudente, SP, Brasil. e-mail: vamilton@unoeste.br 


\section{Introduction}

Toxocariasis, although little recognized as a public health problem, is considered an important worldwide zoonosis (RUBINSKY-ELEFANT et al., 2010). In humans, the principal route of transmission is by ingestion of embryonated Toxocara canis or $T$. cati eggs, which are parasites of dogs and cats, respectively (DESPOMMIER, 2003).

Humans act as paratenic hosts of Toxocara spp. After hatching in the intestine, the larvae migrate through the organism and can cause hemorrhage, necrosis and eosinophilic inflammation, or be encapsulated in granulomas, either being destroyed or remaining viable for many years (MAGNAVAL et al., 2001).

Human toxocariasis is diagnosed based on clinical, epidemiological and laboratory data, primarily using the ELISA test, whose sensitivity ranges from $78.3 \%$ (GLICKMAN et al., 1978) to $100 \%$ (RUBINSKY-ELEFANT et al., 2006; ROLDÁN et al., 2006), and specificity from $86 \%$ (JACQUIER et al., 1991) to $97.4 \%$ (SAVIGNY et al., 1979), for the detection of IgG anti-Toxocara immunoglobulins. In clinical studies on humans, Hubner et al. (2001) and Dziemian et al. (2008) reported that, in chronic cases of the disease, there is high IgG avidity, while low avidity is noted in acute infections. However, the persistence of the antibodies over a long period, due to antigenic stimulation caused by the maintenance of the Toxocara spp. larvae in the tissues of paratenic hosts, can make it difficult to classify the infection as acute or chronic (FENOY et al., 1992; RUBINSKY-ELEFANT et al., 2006).

The literature on the avidity of anti-Toxocara antibodies in hosts is scanty and limited to mice (FENOY et al., 2008; SCHOENARDIE et al., 2014). Therefore, studying the avidity of anti-Toxocara spp. antibodies in other animal models may help shed light on the profile of the humoral immune response to toxocariasis.

This study involved an investigation into the kinetics and avidity of anti-Toxocara canis antibodies in experimentally infected rabbits.

\section{Materials and Methods}

\section{Animals}

Seventeen 4-month old New Zealand White rabbits from the UNOESTE vivarium were used. To confirm the negative diagnosis of enteroparasites, three fecal samples collected in three consecutive weeks prior to infection were analyzed using the Willis-Mollay and Hoffman techniques (HOFFMANN, 1987). The project was approved by the Animal Research Ethics Committee of the University of Western São Paulo - UNOESTE in Presidente Prudente, SP, Brazil (under Protocol 132/09).

\section{Experimental groups}

The rabbits in this study were divided into two groups. The first group consisted of 12 females artificially infected with 1000 T. canis eggs, and the second comprised five uninfected females, which served as control.
Throughout the experimental period, the animals received commercial rabbit feed pellets and water ad libitum and were housed individually in suspended galvanized wire mesh cages in a biotery.

\section{Obtaining Toxocara canis eggs}

T. canis eggs were obtained from adult females which were released from naturally infected puppies kept in the kennel at UNOESTE.

To obtain the eggs, the anterior third of the uteruses of the female nematodes were dissected (FAN et al., 2003) and stored for five weeks at $27{ }^{\circ} \mathrm{C}$ for embryonation. After this period, the material was washed three times in saline solution by centrifugation $(922 \times \mathrm{g}$ ) for three minutes. A total of 1000 embryonated eggs were counted in a Neubauer chamber, and diluted in $3.0 \mathrm{~mL}$ of phosphate buffered saline (PBS) solution for experimental infection.

\section{Infection of the animals}

Prior to experimental infection, the animals were sedated by intraperitonial administration of $30 \mathrm{mg} / \mathrm{kg}$ of combined tiletamine/zolazepam (Zoletil 5\%, Virbac), diluted in saline (KANASHIRO \& CASSU, 2008).

The animals were infected using the procedure described by Pecinali et al. (2005), with minor modifications. The animals were orally inoculated with $3.0 \mathrm{~mL}$ of the solution containing embryonated eggs, using a gastric gavage. Another $3.0 \mathrm{~mL}$ of PBS was administered to the animals via the same route to ensure the passage of the eggs. The control group received only PBS, following the same procedures for the administration of the anesthetic and inoculum.

To obtain the serum, blood samples were collected through puncture of the central auricular artery at the following time points; 0 (pre-infection), 7, 14, 21, 28 and 60 days post-infection (DPI).

\section{Excretory-secretory T. canis antigen (TES) production}

The T. canis excretory-secretory larval antigen (TES) for ELISA was prepared as described previously (SAVIGNY, 1975), with some modifications (RUBINSKY-ELEFANT et al., 2006). Briefly, T. canis eggs collected from the uterus of adult female worms were embryonated after incubation in $2 \%$ formalin for approximately 1 month at $28{ }^{\circ} \mathrm{C}$. Following, the material was washed by centrifugation ( 3 minutes at $1,200 \mathrm{~g}$ ) in $0.9 \% \mathrm{NaCl}$ until the formalin solution was completely removed. Eggshells were broken by slow homogenisation in an Erlenmeyer flask, and L3 larvae were collected by using a Baermann apparatus in serum-free Eagle's medium. The supernatant of the larvae culture was weekly collected, and the protease inhibitor phenylmethylsulphonyl fluoride (PMSF, Sigma, 0.2 M, 5.0 $\mu \mathrm{L} / \mathrm{mL}$ ) added. The collected supernatant was concentrated in Amicon Ultrafiltration units (Millipore, Danvers, MA), dialysed against distilled water, centrifuged $\left(15,000 \mathrm{~g}\right.$ for 30 minutes at $\left.4{ }^{\circ} \mathrm{C}\right)$, and filtered using $0.22 \mu \mathrm{m}$ Millipore membranes. The Lowry method (LOWRY et al., 1951) was employed to determine the protein content. 


\section{ELISA (enzyme-linked immunosorbent assay)}

The ELISA test was performed to evaluate the production of anti-T. canis antibodies, using the protocol described by Savigny et al. (1979) with modifications (RUBINSKY-ELEFANT et al., 2006).

To perform the test, 96-well polystyrene microplates (Corning, Costar, New York, NY) were coated $(1.9 \mu \mathrm{g} / \mathrm{mL}$ antigen/well) with excretion-secretion antigens produced by the T. canis $\left(\mathrm{L}_{3}\right)$ larvae (TES) and tested for 2 hours at $37^{\circ} \mathrm{C}$, followed by 18 hours at $4^{\circ} \mathrm{C}$. The microplates were then washed three times for 5 minutes with phosphate buffered saline (PBS) $0.01 \mathrm{M}, \mathrm{pH} 7.2$, containing $0.05 \%$ Tween-20 (PBS-T). The microplates were blocked with $2.5 \%$ skimmed milk (Molico, Nestlé) in PBS-T (200 $\mu \mathrm{L} /$ well) for 1 hour at $37^{\circ} \mathrm{C}$ and then washed three times with PBS-T.

The serum samples $(100 \mu \mathrm{L} /$ well $)$ were diluted at 1:200 and incubated for 40 minutes at $37{ }^{\circ} \mathrm{C}$, in duplicate. After three washing cycles, the plates were incubated with conjugated goat anti-rabbit IgG $(100 \mu \mathrm{L} /$ well; Sigma-Aldrich A0545, USA) at a dilution of $1: 40,000$ in PBS-T for 40 minutes at $37^{\circ} \mathrm{C}$. After another round of washing, the plates were incubated with chromogenic solution $(100 \mu \mathrm{L} /$ well; OPD Fast-Sigma, St Louis, EUA), comprising ortho-phenylenediamine $(0.4 \mathrm{mg} / \mathrm{mL})$ and $\mathrm{H}_{2} \mathrm{O}_{2}$-urea $(0.4 \mathrm{mg} / \mathrm{mL})$ in $0.05 \mathrm{M}$ of phosphate-citrate buffer for 15 minutes at $37^{\circ} \mathrm{C}$. The reaction was stopped with $\mathrm{H}_{2} \mathrm{SO}_{4} 2 \mathrm{~N}$ (50 $\mu \mathrm{L} /$ well), and the optical densities (OD) were measured at 492 nm (Titertek Multiskan MCC/340, Lab-System, Finland).

The cut-off point was calculated from the mean optical densities of sera from 17 uninfected animals (5 animals in the control group and 12 pre-infection animals) plus two standard deviations. The antibody levels were expressed as reactivity indices (RIs), calculated as the ratio between the absorbance value of the optical density of each tested sample and the optical density at the cut-off point $(0.292)$. The samples with RIs above 1 were considered positive.

\section{Avidity of antibodies (IgG)}

The dissociative method was used to study avidity, with urea as the denaturing agent (HEDMAN et al., 1989). To evaluate the possibility of the denaturing agent acting on the absorbed antigen in the solid phase and interfering in the results, the sensitized and blocked ELISA plate was first treated for 5 minutes with $8 \mathrm{M}$ urea prior to performing the assay. To determine the avidity of antibodies, serum samples and conjugate dilutions were the same for ELISA assay, according to the previous description, except that sera were applied in duplicate to the microtiter wells. After incubation for $40 \mathrm{~min}$ at $37^{\circ} \mathrm{C}$, one well of the doublet was washed with PBS-T three times for $5 \mathrm{~min}$; likewise, the other well was washed with $8 \mathrm{M}$ urea dissolved in PBS-T. The avidity index (AI) was calculated as the ratio between the OD sample treated with urea and the OD sample not treated with urea, multiplied by 100 , according to the formula:

$$
\mathrm{AI}(\%)=(\mathrm{OD} \text { with urea/OD without urea }) \times 100
$$

Only the samples with RIs above 1 were considered for AI calculation. The avidity indices were established according to
Hedman \& Rousseau (1989), where: AI lower than 30\% indicates predominance of low-avidity antibodies; AI between 30 and 50\% indicates intermediate-avidity antibodies; and AI above 50\% indicates high-avidity antibodies.

\section{Statistical analysis}

The mean values of the avidity and reactivity indices were calculated from the data obtained. The AI and RI of the sera of the females were compared using the paired t-test, while the correlation between the two indices was evaluated via a simple linear regression analysis. The adequacy of the model was tested using residual analysis and adjustment of statistics, with a coefficient of determination $\left(R^{2}\right)$. The significance level used in all the comparisons was $5 \%$. All the analyses were performed with the aid of SPSS v. 13.0 software for Windows (FIELD, 2009).

\section{Results}

Seroconversion of the infected animals was observed on the $14^{\text {th }}$ DPI in $41.7 \%$, followed by a gradual increase in RI. Positive RI frequencies of $83.3 \% ; 91.7 \%$ and $100 \%$ were observed on the $21^{\text {st }}, 28^{\text {th }}$ and $60^{\text {th }}$ DPI, respectively.

Only one animal demonstrated seroconversion on the $60^{\text {th }}$ DPI, with a slightly lower RI than that of the other animals $(\mathrm{RI}=4.457)$.

The average RIs were 1.064, 2.264, 3.081 and 4.895 on the $14^{\text {th }}, 21^{\text {st }}, 28^{\text {th }}$ and $60^{\text {th }}$ DPI, respectively (Figure 1 ). The average RIs on the $28^{\text {th }}$ and $60^{\text {th }}$ DPI presented a statistically significant difference $(\mathrm{p}=0.0019)$.

Figure 2 shows the classification of the Avidity Index (AI) of the animals. All the animals that seroconverted had high-avidity antibodies, except for one animal which presented intermediateavidity antibodies $(\mathrm{IA}=46.6 \%)$ on the $14^{\text {th }}$ DPI.

The AI ranged from $46.6 \%$ to $86.6 \%$ (mean $\mathrm{AI}=65.1 \%$ ) at $14 \mathrm{DPI}, 51.0$ to $92.6 \%$ (mean $\mathrm{AI}=67.5 \%$ ) at $21 \mathrm{DPI}$, and

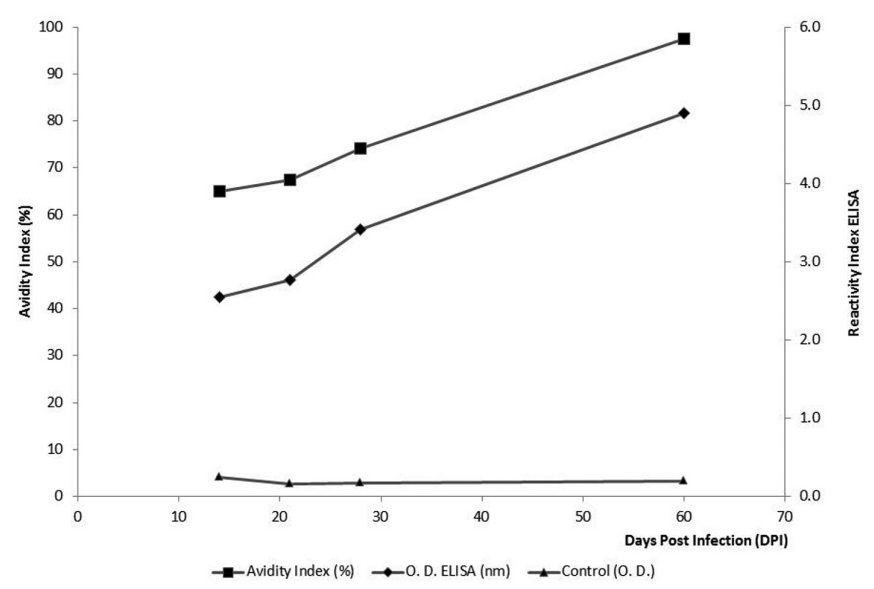

Figure 1. Avidity index (AI; \%) and Reactivity index (RI) for antibodies (IgG) detected by enzyme linked immunosorbent assay (ELISA) in rabbits experimentally infected with Toxocara canis at different post-infection time points (DPI). 


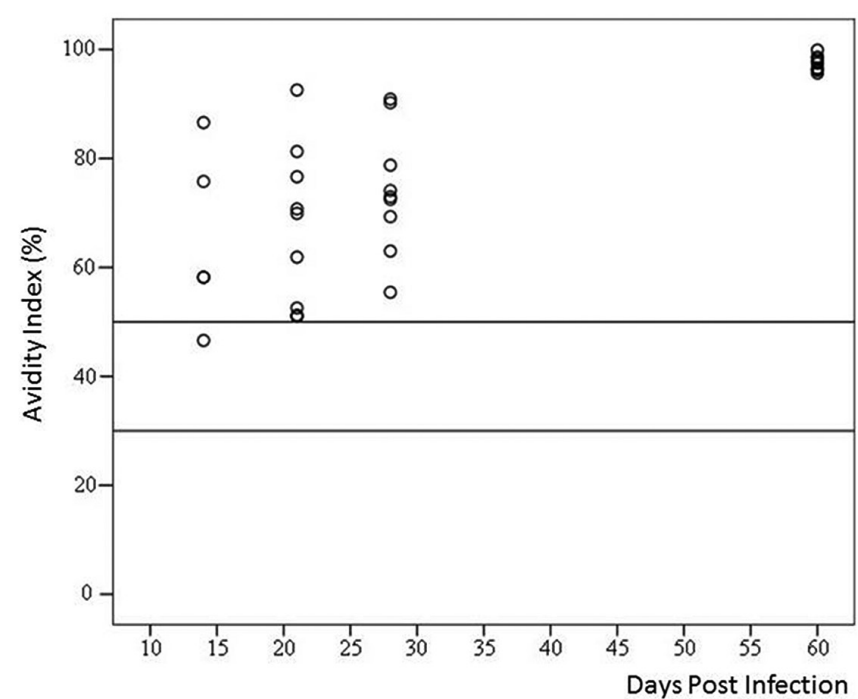

Figure 2. Avidity index (\%) of IgG anti-Toxocara canis in experimentally infected rabbits, detected by enzyme linked immunosorbent assay (ELISA) at different post-infection time points (DPI). Classification of AI: less than 30: predominance of low avidity; higher than or equal to 30 and less than 50: predominance of intermediate avidity; equal to or higher than 50: predominance of high avidity.

Table 1. Correlation coefficient between reactivity and avidity indices for detection of IgG antibodies by enzyme linked immunosorbent assay (ELISA) in rabbits experimentally infected with Toxocara canis at different time points after infection.

\begin{tabular}{cccc}
\hline $\begin{array}{c}\text { Post-infection } \\
\text { Time Points (days) }\end{array}$ & R & CI 95\% & p \\
\hline 7 & NC & - & - \\
14 & NC & - & - \\
21 & 0.3567 & $-0.64-0.91$ & 0.4876 \\
28 & 0.4597 & $-0.56-0.93$ & 0.3590 \\
60 & 0.8765 & $0.36-0.98$ & 0.0096 \\
\hline
\end{tabular}

NC: Not calculated: Reactivity Index of $\operatorname{IgG}<1.0$. R: Correlation coefficient. $p$ : Level of significance. $P$ values $<0.05$ indicates statistical significance.

$55.4 \%$ to $90.9 \%$ (mean $\mathrm{AI}=74.1 \%$ ) at $28 \mathrm{DPI}$. At $60 \mathrm{DPI}$, the AI ranged from $95.7 \%$ to $99.9 \%$ (mean $\mathrm{AI}=97.4 \%$ ).

The correlation between the RI and AI was evaluated 21, 28 and 60 DPI, since the RIs on the $7^{\text {th }}$ and $14^{\text {th }}$ DPI were inconsistent for calculation. A statistically significant correlation $(\mathrm{R}=0.8765 ; \mathrm{p}=0.0096)$ was observed at 60 DPI (Table 1$)$.

\section{Discussion}

The novelty of this study was to evaluate the kinetics and avidity of anti-Toxocara antibodies ( $\mathrm{IgG}$ ) in rabbits experimentally infected with a single dose of embryonated T. canis eggs.

Seroconversion was observed from the $14^{\text {th }}$ DPI, followed by a gradual increase in positive animals over the infection time. Similarly, Morales et al. (2002) verified the same response pattern using Western blot for detecting anti-Toxocara antibodies in rabbits (the same strain and age). Variations in seroconversion time have been observed in paratenic hosts experimentally infected with Toxocara spp. In pigs, anti-Toxocara antibodies were observed at 7 (SOMMERFELT et al., 2001) and 14 DPI (TAIRA et al., 2003) and in sheep at 21 DPI (SANTARÉM et al., 2011). This phenomenon has also been observed in murines, which are considered the experimental model for human toxocariasis. In mice, seroconversion was observed at 7 (OLLERO et al., 2008), 14 (KOLBEKOVÁ et al., 2011) and 23 DPI (LESCANO et al., 2012).

There are a number of factors that may determine the pattern of immune response and pathogenesis in paratenic hosts, including individual characteristics (CUELLAR et al., 2001), the infective dose and number of reinfections (KAYES et al., 1985; OLLERO et al., 2008). Our findings reinforce the statement that individuality may explain a difference in responsiveness to antigens by each individual animal, since some of the rabbits $(41.7 \%)$ seroconverted in the early days of infection (14 DPI), followed by observation of seroconversion at different time points, including one registered at $60 \mathrm{DPI}$.

Experimental studies have shown the influence of infective dose on the immune response to toxocariasis. In pigs experimentally infected with doses of 1000 or 2000 eggs, significant differences were observed in titer values related to dose, with higher titers for the group dosed with 2000 eggs during the period between 2 and 7 weeks post-infection (SOMMERFELT et al., 2001). Havasiová-Reiterová et al. (1995) evaluated the effects of 5 to 2,500 infective Toxocara canis eggs, observing a faster production of antibodies in mice infected with a higher dose of eggs. In our study, the rabbits were infected with a single dose of 1000 eggs, and interestingly, the observed response pattern of the animals was very similar to that described by Morales et al. (2002), using an infective dose of 5000 eggs.

Early antibody response in experimentally infected paratenic hosts may be detected by ELISA (SOMMERFELT et al., 2001), however the detection of specific IgG antibodies, does not allow differentiation between acute and chronic phases of toxocariasis (RUBINSKY-ELEFANT et al., 2010). The use of antibody avidity measurements has been widely employed to distinguish the acute and chronic phases of several parasitic diseases that affect humans, such as schistosomiasis (MOSTAFA et al., 2002), fascioliasis (ABOU-BASHA et al., 2000), neurocysticercosis (MANHANI et al., 2009), toxoplasmosis (CANDOLFI et al., 2007; GAY-ANDRIEU et al., 2009) and toxocariasis (HUBNER et al. 2001; DZIEMIAN et al., 2008).

Regarding human toxocariasis, the chronic phase is characterized by high IgG avidity, while low avidity is observed in acute infections (HUBNER et al., 2001; DZIEMIAN et al., 2008). Some authors, however, find it difficult to classify the infection as acute or chronic, due to the persistence of antibodies over a long period as a consequence of the antigenic stimulation caused by Toxocara spp. larvae (GLICKMAN et al., 1986; FENOY et al., 1992; RUBINSKY-ELEFANT et al., 2006). Therefore, experimental studies, particularly in murines, have been carried out to evaluate whether antibody avidity is a useful model for identification of acute and chronic toxocariasis.

In mice infected with a single dose or with multiple infections of $T$. canis eggs, a high AI (about 50\%) was observed 40 to 60 DPI 
(FENOY et al., 2008). In BALB/c mice infected with a single dose of 1000 eggs, a percentage drop (low avidity: 7.25 to $27.5 \%$ ) was verified at $15 \mathrm{DPI}$, an intermediate avidity for IgG up to $45 \mathrm{DPI}$ (27.5 to $31.4 \%$ ), and IgG AI between 31.4 and $58 \%$ at $60 \mathrm{DPI}$ (SCHOENARDIE et al., 2014). In our study, however, high avidity IgG was detected early after infection (mean AI $=65.1 \%$ ) and gradually increased for at least 2 months (mean AI $=97.4 \%$ ), resulting in a strong association between the Avidity and Reactivity Indices at 60 DPI.

The present study has some limitations. Several experimental studies have evaluated the subclasses of immunoglobulins involved in toxocariasis (KAYES et al., 1985; OLLERO et al., 2008). We used the indirect ELISA based on the detection of total IgG anti-Toxocara, which is currently the standard serological method for the diagnosis of human toxocariasis (RUBINSKY-ELEFANT et al., 2010; MACPHERSON, 2013). In our study, we evaluated a small sample size to minimize the number of evaluated animals. In terms of challenge, the infection of the rabbits was limited to a single dose of 1000 eggs, which has been used in other studies with murine models (XI \& JIN, 1998; CHO et al., 2007; SCHOENARDIE et al., 2014). Thus, future studies are needed, designed to evaluate different subclasses of immunoglobulins and IgG avidity in rabbits subjected to different doses of infection in a long term study, and a larger sample size, to precisely explain the wide individual variations in immune response and to demonstrate the possibility of using rabbits as an animal model for toxocariasis.

Given these considerations and limitations our data suggest that in rabbits infected with $T$. canis, specific IgG antibodies formed early after infection and a high avidity index was maintained at relatively high levels.

\section{References}

Abou-Basha LM, Shehab AY, Osman MM, Farag HF. Specific IgG avidity in acute and chronic human fascioliasis. East Mediterr Health J 2000; 6(5-6): 919-925. PMid:12197349.

Candolfi E, Pastor R, Huber R, Filisetti D, Villard O. IgG avidity assay firms up the diagnosis of acute toxoplasmosis on the first serum sample in immunocompetent pregnant women. Diagn Microbiol Infect Dis 2007; 58(1): 83-88. http://dx.doi.org/10.1016/j.diagmicrobio.

Cho S, Egami M, Ohnuki H, Saito Y, Chinone S, Shichinohe K, et al. Migration behaviour and pathogenesis of five ascarid nematode species in the Mongolian gerbil Meriones unguiculatus. J Helminthol 2007; 81(1): 43-47. http://dx.doi.org/10.1017/S0022149X07212118. PMid:17381866.

Cuéllar C, Fenoy S, Águila C, Guillén JL. Isotype specific immune responses in murine experimental toxocariasis. Mem Inst Oswaldo Cruz 2001; 96(4): 549-553. http://dx.doi.org/10.1590/S0074-02762001000400018. PMid:11391430.

Despommier D. Toxocariasis: clinical aspects, epidemiology, medical ecology, and molecular aspects. Clin Microbiol Rev 2003; 16(2): 265-272. http://dx.doi.org/10.1128/CMR.16.2.265-272.2003. PMid:12692098.

Dziemian E, Zarnowska H, Kołodziej-Sobocińska M, Machnicka B. Determination of the relative avidity of the specific IgG antibodies in human toxocariasis. Parasite Immunol 2008; 30(3): 187-190. http:// dx.doi.org/10.1111/j.1365-3024.2007.01010.x. PMid:18179629.
Fan CK, Lin YH, Du WY, Su KE. Infectivity and pathogenicity of 14-month-cultured embryonated eggs of Toxocara canis in mice. Vet Parasitol 2003; 113(2): 145-155. http://dx.doi.org/10.1016/S03044017(03)00046-3. PMid:12695039.

Fenoy S, Cuéllar C, Aguila C, Guillén JL. Persistence of immune response in human toxocariasis as measured by ELISA. Int J Parasitol 1992; 22(7): 1037-1038. http://dx.doi.org/10.1016/0020-7519(92)90067-U. PMid:1459782.

Fenoy S, Rodero M, Pons E, Aguila C, Cuéllar C. Follow-up of antibody avidity in BALB/c mice infected with Toxocara canis. Parasitology 2008; 135(6): 725-733. http://dx.doi.org/10.1017/S0031182008004368. PMid:18413003.

Field AP. Discovering Statistics Using SPSS. 3rd ed. London: Sage Publications; 2009.

Gay-Andrieu F, Fricker-Hidalgo H, Sickinger E, Espern A, Brenier-Pinchart MP, Braun H-B, et al. Comparative evaluation of the ARCHITECT Toxo IgG, IgM, and IgG Avidity assays for anti-Toxoplasma antibodies detection in pregnant women sera. Diagn Microbiol Infect Dis 2009; 65(3): 279-287. http://dx.doi.org/10.1016/j.diagmicrobio.2009.07.013. PMid:19822270.

Glickman L, Schantz P, Dombroske R, Cypess R. Evaluation of serodiagnostic tests for visceral larva migrans. Am J Trop Med Hyg 1978; 27(3): 492-498. PMid:98065.

Glickman LT, Schantz PM, Grieve RB. Toxocariasis. In: Walls KW, Schantz PM, editors. Helmintic diseases. New York: Academic Press; 1986. vol. 1. Immunodiagnosis of Parasitic Diseases.

Havasiová-Reiterová K, Tomasovicová O, Dubinský P. Effect of various doses of infective Toxocara canis and Toxocara cati eggs on the humoral response and distribution of larvae in mice. Parasitol Res 1995; 81(1): 13-17. http://dx.doi.org/10.1007/BF00932411. PMid:7724509.

Hedman K, Lappalainen M, Seppäiä I, Mäkelä O. Recent primary Toxoplasma infection indicated by a low avidity of specific IgG. J Infect Dis 1989; 159(4): 736-740. http://dx.doi.org/10.1093/infdis/159.4.736. PMid:2926163.

Hedman K, Rousseau SA. Measurement of avidity of specific IgG for verification of recent primary rubella. J Med Virol 1989; 27(4): 288-292. http://dx.doi.org/10.1002/jmv.1890270406. PMid:2723615.

Hoffmann RP. Diagnóstico de parasitismo veterinário. Porto Alegre: Sulina; 1987.

Hübner J, Uhlíková M, Leissová M. Diagnosis of the early phase of larval toxocariasis using IgG avidity. Epidemiol Mikrobiol Imunol 2001; 50(2): 67-70. PMid:11329729.

Jacquier P, Gottstein B, Stingelin Y, Eckert J. Immunodiagnosis of toxocarosis in humans: evaluation of a new enzyme-linked immunosorbent assay kit. J Clin Microbiol 1991; 29(9): 1831-1835. PMid:1774303.

Kanashiro GP, Cassú RN. Anestesia de animais selvagens e de laboratório. In: Andrade SF. Manual de terapêutica veterinária. 3rd ed. Roca: São Paulo; 2008.

Kayes SG, Omholt PE, Grieve RB. Immune responses of CBA/J mice to graded infections with Toxocara canis. Infect Immun 1985; 48(3): 697-703. PMid:3997242.

Kolbeková P, Větvička D, Svoboda J, Skirnisson K, Leissová M, Syrůček $\mathrm{M}$, et al. Toxocara canis larvae reinfecting BALB/c mice exhibit accelerated speed of migration to the host CNS. Parasitol Res 2011; 109(5): $1267-$ 1278. http://dx.doi.org/10.1007/s00436-011-2371-y. PMid:21537988. 
Lescano SAZ, Nakhle MC, Ribeiro MCSA, Chieffi PP. IgG antibody responses in mice coinfected with Toxocara canis and other helminths or protozoan parasites. Rev Inst Med Trop Sao Paulo 2012; 54(3): 145-152. http://dx.doi.org/10.1590/S0036-46652012000300006. PMid:22634886.

Lowry A, Rosebrough NJ, Farr AL, Randall RJ. Protein measurement with the folin phenol reagent. J Biol Chem 1951; 193(1): 265-275. PMid:14907713.

Macpherson CN. The epidemiology and public health importance of toxocariasis: a zoonosis of global importance. Int J Parasitol 2013; 43(12-13): 999-1008. http://dx.doi.org/10.1016/j.ijpara.2013.07.004. PMid:23954435.

Magnaval JF, Glickman LT, Dorchies P, Morassin B. Highlights of human toxocariasis. Korean J Parasitol 2001; 39(1): 1-11. http://dx.doi. org/10.3347/kjp.2001.39.1.1. PMid:11301585.

Manhani MN, Ribeiro VS, Silva DAO, Costa-Cruz JM. Specific IgG avidity in active and inactive human neurocysticercosis. Diagn Microbiol Infect Dis 2009; 65(2): 211-213. http://dx.doi.org/10.1016/j. diagmicrobio.2009.05.018. PMid:19748437.

Morales OL, Lopez MC, Nicholls RS, Agudelo C. Identification of Toxocara canis antigens by Western blot in experimentally infected rabbits. Rev Inst Med Trop Sao Paulo 2002; 44(4): 213-216. http://dx.doi.org/10.1590/ S0036-46652002000400006. PMid:12219113.

Mostafa NE, Awad A, Shalaby M. Low avidity IgG antibodies in diagnosis of recent human schistosomiasis. J Egypt Soc Parasitol 2002; 32(3): 979 985. PMid:12512829.

Ollero MD, Fenoy S, Cuéllar C, Guillén JL, Del Aguila C. Experimental toxocariosis in BALB/c mice: effect of the inoculation dose on brain and eye involvement. Acta Trop 2008; 105(2): 124-130. http://dx.doi. org/10.1016/j.actatropica.2007.11.001. PMid:18093569.

Pecinali NR, Gomes RN, Amendoeira FC, Bastos AC, Martins MJ, Pegado CS, et al. Influence of murine Toxocara canis infection on plasma and bronchoalveolar lavage fluid eosinophil numbers and its correlation with cytokine levels. Vet Parasitol 2005; 134(1-2): 121-130. http://dx.doi. org/10.1016/j.vetpar.2005.06.022. PMid:16168564.

Roldán W, Cornejo W, Espinoza Y. Evaluation of the dot enzyme-linked immunosorbent assay in comparison with standard ELISA for the immunodiagnosis of human toxocariasis. Mem Inst Oswaldo Cruz 2006;
101(1): 71-74. http://dx.doi.org/10.1590/S0074-02762006000100013. PMid:16612511.

Rubinsky-Elefant G, Hirata CE, Yamamoto JH, Ferreira MU. Human toxocariasis: diagnosis, worldwide seroprevalences and clinical expression of the systemic and ocular forms. Ann Trop Med Parasitol 2010; 104(1): 3-23. http://dx.doi.org/10.1179/136485910X12607012373957. PMid:20149289.

Rubinsky-Elefant G, Shimizu SH, Sanchez MCA, Jacob CMA, Ferreira AW. A serological follow-up of toxocariasis patients after chemotherapy based on the detection of $\operatorname{IgG}$, IgA, and IgE antibodies by enzyme-linked immunosorbent assay. J Clin Lab Anal 2006; 20(4): 164-172. http:// dx.doi.org/10.1002/jcla.20126. PMid:16874812.

Santarém VA, Chesine PAF, Lamers BEL, Rubinsky-Elefant G, Giuffrida R. Anti-Toxocara spp. antibodies in sheep from southeastern Brazil Vet Parasitol 2011; 179(1-3): 283-286. http://dx.doi.org/10.1016/j. vetpar.2011.01.050. PMid:21330057.

Savigny DH, Voller A, Woodruff AW. Toxocariasis: serological diagnosis by enzyme immunoassay. J Clin Pathol 1979; 32(3): 284-288. http:// dx.doi.org/10.1136/jcp.32.3.284. PMid:372253.

Savigny DH. In vitro maintenance of Toxocara canis larvae and a simple method for the production of Toxocara ES antigens for use in serodiagnostic tests for visceral larva migrans. J Parasitol 1975; 61(4): 781-782. http:// dx.doi.org/10.2307/3279492. PMid:1165568.

Schoenardie ER, Scaini CJ, Avila LF, Sperotto RL, Borsuk S, Felicetti $\mathrm{CD}$, et al. Determination of IgG avidity in $\mathrm{BALB} / \mathrm{c}$ mice experimentally infected with Toxocara canis. Rev Bras Parasitol Vet 2014; 23(3): 403-406. http://dx.doi.org/10.1590/S1984-29612014060. PMid:25271464.

Sommerfelt IE, Santillán G, Lopez C, Ribicich M, Franco AJ. Immunological and hematological response in experimental Toxocara canis-infected pigs. Vet Parasitol 2001; 96(2): 127-134. http://dx.doi.org/10.1016/S03044017(00)00423-4. PMid:11230919.

Taira K, Permin A, Kapel CM. Establishment and migration pattern of Toxocara canis larvae in chickens. Parasitol Res 2003; 90(6): 521-523. http://dx.doi.org/10.1007/s00436-003-0894-6. PMid:12827506.

Xi WG, Jin LZ. A novel method for the recovery of Toxocara canis in mice. J Helminthol 1998; 72(2): 183-184. http://dx.doi.org/10.1017/ S0022149X00016382. PMid:9687601. 